\title{
CLINICAL TRIAL OF ETOMIDATE
}

\section{Preliminary Observations On A New Non-barbiturate Induction Agent \\ C.E. Famewo and C.O. Odugbesan}

BARBITURATES are the most commonly used intravenous agents for the induction of general anaesthesia. They are well tolerated and give a smooth fast induction in most patients. However, their use may be relatively or absolutely contraindicated in patients with marked hypotension, labile cardiovascular systems, severe asthma and acute intermittent porphyria. Hence, the search for alternative non-barbiturate agents for anaesthesia induction. This is a preliminary report of our observations with etomidate, a new ultra short-acting non-barbiturate agent for the induction of anaesthesia.

Etomidate is a derivative of imidazole-carboxylate ${ }^{1}$ (Figure 1). It is provided as the sulfate, a white powder, bottled in $30 \mathrm{mg}$ doses. This is dissolved just prior to<smiles>CCOC(=O)c1cncn1C(C)c1ccccc1</smiles>

FIGURE 1. Chemical structure of etomidate. (Ethyl-1-methylbenzyl-imidazole-5-carboxylate).

use in the $20 \mathrm{ml}$ of solvent provided to give a solution of $1.5 \mathrm{mg}$ per ml. It contains no bacteriostatics. Etomidate has no analgesic properties and should therefore be followed by other anaesthetic agents for the maintenance of anaesthesia.

Etomidate was first used clinically in 1972 by Doenicke ${ }^{2}$ after experimental investigations in rats by Janssen, et al. ${ }^{1}$ On the basis of their reports, we felt justified to carry out this preliminary study on our patients.

\section{METHod}

A total of 32 patients were studied. They were undergoing different minor surgical procedures as listed in Table I.

C.E. Famewo, M.B., B.S., Dip.Anaes., F.R.C.P.(C) and C.O. Odugbesan, M.D., Dip.Anaes., F.R.C.P.(C), Department of Anaesthesia, University of Ibadan, and University College Hospital, Ibadan, Nigeria. 


\begin{tabular}{lc}
\hline \hline \multicolumn{1}{c}{ Type of surgical procedure } & $\begin{array}{c}\text { Number of } \\
\text { patients }\end{array}$ \\
\hline $\begin{array}{l}\text { A. Ear, nose and throat (ENT): } \\
\text { e.g. E.U.A., myringotomy, } \\
\text { polypectomy, etc. }\end{array}$ & 18 \\
$\begin{array}{l}\text { B. General surgical: e.g. breast } \\
\text { biopsy, incision and drainage } \\
\text { of abscess, etc. }\end{array}$ & 8 \\
$\begin{array}{l}\text { C. Orthopaedic: e.g. change of } \\
\text { P.O.P. cast, closed reduction of } \\
\text { fracture, etc. } \\
\quad \text { Total }\end{array}$ & 6 \\
\hline
\end{tabular}

\section{Dose Schedule}

The dose of etomidate used for this study was $0.3 \mathrm{mg} / \mathrm{kg}$ body weight. This was chosen as the optimum sleep dose after smaller dose schedules had failed to give satisfactory conditions at induction.

\section{Premedication}

Seventeen of the 32 patients received atropine and meperidine (pethidine) premedication by intramuscular injection on the ward about 45 minutes before induction. The remaining 15 patients received no premedication on the ward but were given atropine intravenously a few minutes before induction.

\section{Induction of anaesthesia}

Base line blood pressure, pulse and respiratory rate were taken. Etomidate in a dose of $0.3 \mathrm{mg} / \mathrm{kg}$ was injected intravenously over about 20 seconds. Following etomidate injection, the following observations were made:

1. Time to loss of consciousness from end of injection.

2. Pulse rate and blood pressure.

3. Respiratory rate and depth of respiration.

\section{Maintenance of anaesthesia}

Nitrous oxide and oxygen in the ratio of 2 to 1 and halothane were administered by face-mask after the post-etomidate readings of the pulse rate, blood pressure and respiration rate had been taken.

\section{Results}

Etomidate in the dose used gave smooth and fast induction of anaesthesia in all but two patients that had market myoclonic movements.

\section{Time to loss of consciousness}

The average time to loss of consciousness (as determined by fall of the outstretched arm from the end of injection) was $15.7 \mathrm{sec}$ in the premedicated group and $18.2 \mathrm{sec}$ in the unpremedicated group. 
TABLE II

\begin{tabular}{|c|c|}
\hline $\begin{array}{c}\text { Premedicated group } \\
\text { (Intramuscular Meperidine and } \\
\text { Atropine) }\end{array}$ & $\begin{array}{l}\text { Unpremedicated group } \\
\text { (Intravenous Atropine) }\end{array}$ \\
\hline $\begin{array}{l}\text { Pre-induction } \\
\text { Mean pulse rate } 110 / \mathrm{min} \\
\text { Mean blood pressure } 124 / 70 \mathrm{~mm} \mathrm{Hg} \\
\text { Mean respiration rate } 21 / \mathrm{min}\end{array}$ & $\begin{array}{l}\text { Pre-induction } \\
115 / \mathrm{min} \\
128 / 70 \mathrm{~mm} \mathrm{Hg} \\
22 / \mathrm{min}\end{array}$ \\
\hline $\begin{array}{l}\text { Post-induction } \\
\text { Mean pulse rate } 114 / \mathrm{min} \\
\text { Mean blood pressure } 125 / 70 \mathrm{~mm} \mathrm{Hg} \\
\text { Mean respiratory rate } 24 / \mathrm{min}\end{array}$ & $\begin{array}{l}\text { Post-induction } \\
120 / \mathrm{min} \\
130 / 70 \mathrm{~mm} \mathrm{Hg} \\
24 / \mathrm{min}\end{array}$ \\
\hline
\end{tabular}

\section{Pain}

Nine patients (five premedicated and four unpremedicated) complained of pain during the intravenous injection of etomidate, being an incidence of 28 per cent. The pain disappeared on flushing with water for injection. Seven out of these nine patients had the injection site on the dorsum of the hand.

\section{Myoclonic movements}

Twelve patients ( 37.5 per cent) had myoclonic movements during induction. These were generally mild and self-limiting except in two patients ( 6.25 per cent) where diazepam had to be given to terminate them.

\section{Cardiovascular system}

There was a tendency towards a small increase in the pulse rate and blood pressure following etomidate injection. However, these increases were statistically not significant (Table II).

\section{Respiratory system}

From clinical observation, respiratory rate and depth were fairly well sustained after etomidate injection except in the two patients with severe myoclonic movements, one of whom had a short period of apnoea which did not require assisted ventilation.

\section{Discussion}

Etomidate offers some advantages as an agent for induction of anaesthesia. Induction was usually fast and smooth. We were particularly impressed that the heart rate and blood pressure were not significantly changed after etomidate injection. This is an important advantage over thiopentone, especially in patients with labile cardiovascular systems. Our findings are similar to those of Doenicke, ${ }^{3}$ et al. and more recently Gooding and Corssen. ${ }^{4}$

The two undesirable side-effects we have found so far are the rather frequent occurrence of myoclonic or involuntary movements as well as pain on injection of the drug in some of the patients. Further work is in progress to find ways and means of overcoming these side effects. Based on our present preliminary experience, etomidate looks promising and further clinical investigations are desirable. 


\section{SUMMARY}

This is a preliminary report of our clinical experience with etomidate, a new intravenous non-barbiturate anaesthetic agent. Thirty-two patients undergoing minor surgical procedures were anaesthetized, induction being with etomidate 0.3 $\mathrm{mg} / \mathrm{kg}$ body weight. Induction was fast and smooth. Twenty-eight per cent of the patients complained of pain at site of injection but the pain disappeared on flushing with water for injection. Following etomidate injection, 37.5 per cent of patients developed myoclonic movements which were usually mild and self-limiting. We were impressed by the relative stability of the cardiovascular and respiratory systems. Etomidate looks promising and further work is in progress on other aspects of this drug.

\section{ACKNOWLEDGMENTS}

We wish to thank Professor S.A. Oduntan, Head of Department of Anaesthesia, University College Hospital, Ibadan for making this study possible and for his valuable contribution.

Etomidate was supplied by Janssen Pharmaceutical.

\section{RÉSUMÉ}

Les auteurs rapportent leurs premières impressions cliniques de l'etomidate, un nouvel anesthésique intraveineux non barbiturique. L'etomidate a été utilisé comme agent d'induction chez 32 malades devant subir une chirurgie mineure. La dose utilisée a été de $0.3 \mathrm{mg} / \mathrm{kilo}$.

L'induction était rapide et facile. Ving-huit pour cent des patients se sont plaints de douleur au site d'injection, douleur qui disparaissait lorsque l'on irriguait la veine. Trente-sept pour cent des patients ont présenté des mouvements cloniques légers, mouvements qui cessaient d'eux-mêmes généralement. Nous avons été impressionnés par la stabilité des paramètres cardiovasculaires et respiratoires.

C'est un agent qui nous apparaît prometteur et nous poursuivons notre étude.

\section{REFERENCES}

1. Janssen, P.A.J., Niemegeers, C.J.E., Schellekens, K.H.L., \& Lenaerts, F.M. Etomidate, R- $(+)$-Ethyl-l-( $\alpha$-methylbenzyl) imidazole-5-carboxylate (R16659). Arzneimittelforsh. (Drug Res.) 21: 1234 (1971).

2. Doenicke, A. Clinical experimental studies and first report on clinical experience with a new I.V. hypnotic. Proceedings of the 6th International Refresher course on Clinical Anaesthesiology, Vienna, May 21-25, 1973.

3. Doenicke, A., Gabany, D., Lemche, H., \& Schurx-Bulichim. Circulatory behaviour nnd myocardial function after administration of three short I.V. hypnotics - etomidate, propanidid, and methohexital. Anaesthetist 23: 108-115 (1974).

4. Goodrnc, J.M. \& ConseEv, D.G. Etomidate: An ultrashort-acting non-barbiturate agent for anaesthesia induction. Anaesthesia and Analgesia Current Researches, Vol. 55, No. 2 (March-April, 1976). 